\title{
Comparative Study on Application of Ecological Architecture Concept on Javanese Traditional House in Central Jawa
}

\author{
Jarwa Prasetya S. Handoko \\ Department of Architecture \\ Universitas Islam Indonesia \\ Yogyakarta, Indonesia \\ jarwa.prasetya@uii.ac.id
}

\begin{abstract}
Ecological architecture is an architectural concept that emphasizes harmony between the artificial environment and the surrounding natural conditions. The application of this concept is needed now, with a decrease in environmental quality, which is characterized by a lot of environmental damage caused by the construction of buildings and other facilities. This phenomenon must be addressed jointly by architects, government, and society. Traditional Houses are one of the architectural works which are referred to as one of the ecological architectural works. So it is necessary to examine the extent of the application of ecological architecture to traditional house buildings, especially Java so that it is expected to get lessons learned from traditional Javanese home designs that can be applied in today's building design. Therefore, it is necessary to conduct a study that evaluates the concept of ecological architecture in traditional Javanese home design. This research is an exploratory study conducted with descriptive methods related to the design of Javanese Traditional Houses related to the application of ecological architectural concepts in the design of Javanese Traditional Houses. This study took a case study of 3 (three) varieties of Javanese Traditional Houses in Central Java. With this article, it is expected to provide an overview of the application of the concept of ecological architecture in Javanese Traditional Houses design and to know what aspects of the ecological architecture have been applied to the design of Javanese Traditional Houses. From this study it can be concluded that traditional houses apply the concept of ecological architecture in several aspects. This is influenced by site conditions, location, and climate conditions.
\end{abstract}

Keywords: comparative study, ecological architecture, Javanese Traditional Houses

\section{INTRODUCTION}

This The current issue, which was happened in our habitat, is Environmental degradation, which has impacted global warming and the energy crisis. Human activity in their lives used fossil fuels and deforestation that are producing greenhouse gases that have resulted in global warming and climate change, and this has impacted an environmental crisis [1]. Currently, 40 percent of all energy consumption and greenhouse gas emission on the world are raised by construction sectors. [1] [2].

Architecture, as the built environment has an important role in this issue. Based on research, one of the biggest contributors to energy usage is from the building sector. The architect must start to be responsible for environmental issues. Ecological architecture is related to sustainability in Architecture.

Sustainability is a concept of development which become one of the solutions for us. Thus, Ecological architecture is one of the sustainability concepts. The application of this concept is needed, a decrease in environmental quality, which is characterized by a lot of environmental damage caused by the construction of buildings and other facilities. This phenomenon must be addressed jointly by architects, government, and society.

Traditional Houses are one of the architectural works which are referred to as one of the ecological architectural works. So it is necessary to examine the extent of the application of ecological architecture to traditional house buildings, especially in Central Java

So, that it is expected to get lessons learned from Javanese traditional Houses designs that can be applied in today's building design. Therefore, it is necessary to conduct a study that examines the concept of ecological architecture in traditional Javanese home design.

\section{METHODS}

This study aims to examine Javanese Traditional Houses based on ecological architecture principles theories by Ryn and Cowel [3]

This research is a comparative study conducted with descriptive methods related to the application of ecological architectural principles in the design of Javanese Traditional Houses. This study took a case study of 3 (three) varieties of Javanese Traditional Houses in Central Java.

Comparative studies are commonly used by social researchers in compiling scientific research with the generalization of cross-border research and not prone to the ethnic, social culture of a particular society [4] and the comparative study emphasizes social observation is not limited to one particular territory [5]. 


\section{OBJECTIVES}

This study expected :

1. To provide an overview of the application of the concept of ecological architecture in Javanese Traditional Houses design.

2. To know what aspects of ecological architecture which are already existed in the design of Javanese Traditional Houses and can be applied to the new building.

\section{LITERATURE REVIEW}

Ryn and Cowel [3] stated if we are to create a sustainable world-one in which we are accountable to the needs of all future generations and all living creatures-we must recognize that our present forms of agriculture, architecture, engineering, and technology are deeply flawed.

Ryn and Cowel [3] also stated that to create a sustainable world. We must transform these practices. We must infuse the design of products, buildings, and landscapes with a rich and detailed understanding of ecology. They stated five Principles of Ecological Design :

1. The solution grows from a place. The ecological design begins with the knowledge of a particular area. Moreover, it is small-scale and direct, responsive to both local conditions and local people. Nature becomes a solution for every problem in the site.

2. Ecological accounting informs design. Trace the environmental impacts of an existing or proposed plan. Count the environmental aspect of a plan and be a climate-responsive building by conserving energy.

3. Design with nature. By working with living processes, we respect the needs of all species while meeting our own. Respect the site condition by working with the living process.

4. Everyone is a designer. Listen to every voice in the design process. Everyone is a designer participant. The design should respect the user.

5. Make nature visible. De-natured environments ignore our needs and our potential for studying. Effective design helps inform us of our place within nature. The design should respect the site.

\section{RESULTS AND DisCUSSION}

\section{A. Building Case Study}

Javanese traditional house was chosen as a sample of existing coastal buildings, in the mountains and lowlands. Selected as a sample of three buildings with three different topographic characters.

\section{1) Javanese Traditional House in Wonosoco, Kabupaten Kudus.}

Representing buildings in the coastal area,
Wonosoco Village is located at the southern end of the Undaan Sitrict, Kudus selescted as a sample discussion of this study.

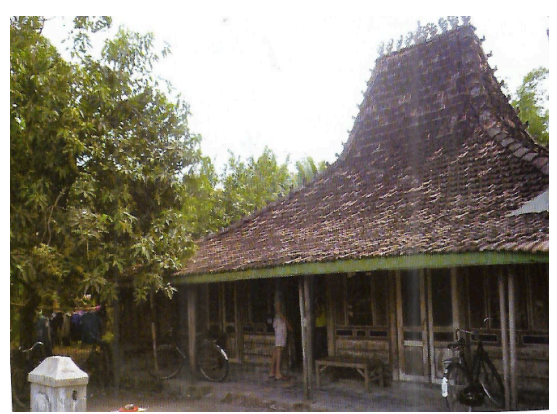

Fig 1. Javanese Traditional House in Kudus. [6]

\section{2) Javanese Traditional House in Purbayan kotagede, Yogyakarta.}

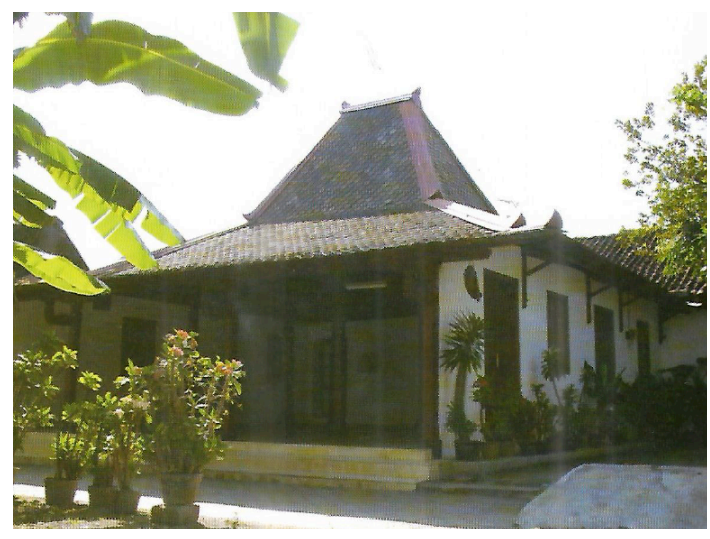

Fig 2. Javanese Traditional House in Purbayan [6]

Representing the selected lowland area Purbayan Village. Purbayan Village is a nonagrarian village located in Kotagede, Yogyakarta.

\section{3) Javanese Traditional House in Selo, Kabupaten Boyolali.}

Representing the mountains area the selected Javanese building in Selo. Selo is in the Merapi Merbabu area, which is included in the Boyolali Regency.

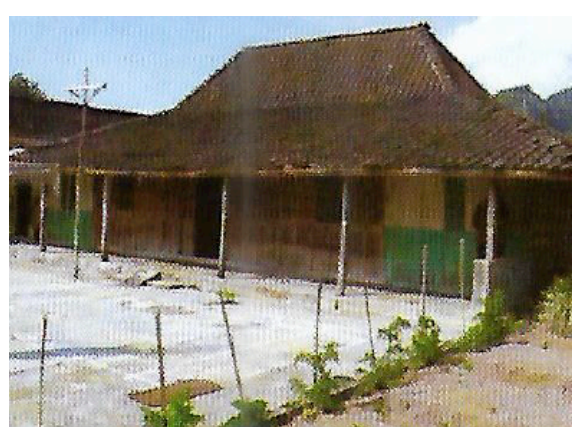

Fig 3. Javanese Traditional House in Selo [6] 


\section{B. Results}

This research data comes from secondary data, including reference books related to traditional architecture and some journals related to traditional architecture and Ecological Architecture. At the data processing stage, each case study building data is grouped into five data categories, namely: Type of Plan, Building Orientation, Spatial Layout, Building elements, and Architectural Elements.

The type of plan category discusses whether traditional building case studies use single stories or multi-stories type for their plan. Data that correlate with orientation and spatial layout presented data related to the direction of the main building and the pattern of building mass compared to the contour conditions of the land used. As for the data related to construction and architectural elements, it collects data associated with the structural system and building infrastructure and building materials chosen in each case study building. The complete data obtained at the data collection stage is shown in the table below:

For data type of plan, the three case study buildings are single-story buildings. As for building orientation, the three case study buildings chose the direction of the building towards the road.

For spatial layout data of Javanese Traditional House in Wonosoco, Kudus Regency, and House in Selo, Boyolali Regency has a spatial layout following the contours of existing land conditions. That is different from in Purbayan Kotegede, where Kotagede's spatial planning is based on the division of functions of activities. Residential patterns related to economic events are separated based on the type of occupied of the local population.

While the data regarding building elements, the three buildings have similarities in the roof element, where all three use a wooden roof structure for the building, but for the walls have differences. For the building of Javanese houses in Kudus and Boyolali, use a wooden board and woven bamboo while in Kotagede already use stone walls as elements of the walls. For data related to architectural elements, the three case study buildings have similarities made of wooden boards and wooden structures.
TABLE 1. DATA CATEGORY

\begin{tabular}{|c|c|c|c|}
\hline $\begin{array}{l}\text { Data } \\
\text { Category }\end{array}$ & $\begin{array}{l}\text { Javanese } \\
\text { Traditional } \\
\text { House in } \\
\text { Wonosoco, } \\
\text { Kabupaten } \\
\text { Kudus }\end{array}$ & $\begin{array}{l}\text { Javanese } \\
\text { Traditional } \\
\text { House in } \\
\text { Purbayan } \\
\text { kotagede, } \\
\text { Yogyakarta }\end{array}$ & $\begin{array}{l}\text { Javanese } \\
\text { Traditional } \\
\text { House in } \\
\text { Selo, } \\
\text { Kabupaten } \\
\text { Boyolali. }\end{array}$ \\
\hline $\begin{array}{l}\text { Type of } \\
\text { Plan }\end{array}$ & Single stories & Single stories & Single stories \\
\hline $\begin{array}{l}\text { Orientati } \\
\text { on }\end{array}$ & $\begin{array}{l}\text { The orientation } \\
\text { of the building } \\
\text { towards the } \\
\text { road }\end{array}$ & $\begin{array}{l}\text { The } \\
\text { orientation of } \\
\text { the building } \\
\text { towards the } \\
\text { road }\end{array}$ & $\begin{array}{l}\text { The } \\
\text { orientation of } \\
\text { the building } \\
\text { towards the } \\
\text { road }\end{array}$ \\
\hline $\begin{array}{l}\text { Spatial } \\
\text { Layout }\end{array}$ & $\begin{array}{l}\text { Wonosoco } \\
\text { Village located } \\
\text { at the southern } \\
\text { end of Undaan } \\
\text { District. } \\
\text { This village has } \\
\text { a flat } \\
\text { geographical } \\
\text { condition and is } \\
\text { more contoured } \\
\text { to the southeast. } \\
\text { The Wonosoco } \\
\text { hamlet } \\
\text { settlement } \\
\text { pattern } \\
\text { generally } \\
\text { spreads, not } \\
\text { forming a mass } \\
\text { group }\end{array}$ & $\begin{array}{l}\text { Kotagede } \\
\text { spatial } \\
\text { planning is } \\
\text { based on the } \\
\text { division of } \\
\text { functions of } \\
\text { activities. } \\
\text { Residential } \\
\text { patterns related } \\
\text { to economic } \\
\text { activities are } \\
\text { separated } \\
\text { based on the } \\
\text { type of activity } \\
\text { of the local } \\
\text { population. }\end{array}$ & $\begin{array}{l}\text { The use of } \\
\text { settlement } \\
\text { land is spread } \\
\text { locally and in } \\
\text { groups, } \\
\text { occupying the } \\
\text { hills in the } \\
\text { relief area. }\end{array}$ \\
\hline $\begin{array}{l}\text { Building } \\
\text { Element }\end{array}$ & $\begin{array}{l}\text { The walls are of } \\
\text { wooden boards. } \\
\text { And in the form } \\
\text { of joglo roof } \\
\text { architecture, } \\
\text { pyramid and } \\
\text { village roof, } \\
\text { with teak wood } \\
\text { roof frame } \\
\text { material, roofing } \\
\text { material made } \\
\text { of clay tile. }\end{array}$ & $\begin{array}{l}\text { The material of } \\
\text { the stone walls, } \\
\text { with a wooden } \\
\text { roof structure } \\
\text { material, and } \\
\text { roof covering } \\
\text { from clay tile. }\end{array}$ & $\begin{array}{l}\text { The wall } \\
\text { material is } \\
\text { wood and } \\
\text { woven } \\
\text { bamboo. The } \\
\text { roof structure } \\
\text { uses teak } \\
\text { wood and } \\
\text { roof covering } \\
\text { material from } \\
\text { clay tile. The } \\
\text { architecture } \\
\text { used generally } \\
\text { uses the shape } \\
\text { of the } \\
\text { pyramid roof } \\
\text { and village } \\
\text { roof. }\end{array}$ \\
\hline $\begin{array}{l}\text { Architect } \\
\text { ural } \\
\text { Element }\end{array}$ & $\begin{array}{l}\text { The foundation } \\
\text { uses river stone } \\
\text { and umpak, the } \\
\text { floor uses a } \\
\text { terrazzo, the } \\
\text { main pillar of } \\
\text { the teak lanang } \\
\text { wooden house. } \\
\text { Door and } \\
\text { window } \\
\text { materials also } \\
\text { use wooden } \\
\text { boards. }\end{array}$ & $\begin{array}{l}\text { Batu Kali } \\
\text { foundation, } \\
\text { plastered floors, } \\
\text { doors and } \\
\text { windows, main } \\
\text { column } \\
\text { structure of teak } \\
\text { wood. }\end{array}$ & $\begin{array}{l}\text { Stone } \\
\text { foundations, } \\
\text { plastered } \\
\text { floors, main } \\
\text { structures of } \\
\text { buildings } \\
\text { using wooden } \\
\text { beams. }\end{array}$ \\
\hline
\end{tabular}

Source : Author Analysis, 2019 


\section{TABLE 2. SUMMARY DISCUSSION BASED ON ECOLOGICAL ARCHITECTURE PARAMETERS}

\begin{tabular}{|c|c|c|c|c|}
\hline $\begin{array}{l}\text { Ecological } \\
\text { Architecture } \\
\text { Parameters }\end{array}$ & $\begin{array}{c}\text { Javanese Traditional } \\
\text { House in Wonosoco, } \\
\text { Kabupaten Kudus }\end{array}$ & $\begin{array}{c}\text { Javanese Traditional } \\
\text { House in Purbayan } \\
\text { Kotagede, Yogyakarta }\end{array}$ & $\begin{array}{c}\text { Javanese Traditional } \\
\text { House in Selo, } \\
\text { Kabupaten Boyolali. }\end{array}$ & $\begin{array}{c}\text { Javanese Traditional } \\
\text { House in Central } \\
\text { Jawa. }\end{array}$ \\
\hline $\begin{array}{l}\text { Solution grows from } \\
\text { place- } \\
\text { Responsive to both } \\
\text { local condition and } \\
\text { people. }\end{array}$ & $\begin{array}{l}\text { In the building element } \\
\text { design, the use of local } \\
\text { meterial, wooden planks } \\
\text { and teak wood as the main } \\
\text { building frame and the roof } \\
\text { frame show. }\end{array}$ & $\begin{array}{l}\text { The choice of stone wall } \\
\text { material in which the } \\
\text { material is abundant } \\
\text { local material. }\end{array}$ & $\begin{array}{l}\text { Selection of bamboo } \\
\text { woven wall material } \\
\text { where the material is local } \\
\text { material. }\end{array}$ & $\begin{array}{l}\text { The choice of building } \\
\text { materials for instance } \\
\text { building frames, walls } \\
\text { and other architectural } \\
\text { elements, chooses local } \\
\text { materials. }\end{array}$ \\
\hline $\begin{array}{l}\text { Ecological } \\
\text { Accounting informs } \\
\text { design } \\
\text { Be a climate responsive } \\
\text { building by conserving } \\
\text { energy. }\end{array}$ & $\begin{array}{l}\text { The use of wooden board } \\
\text { wall material allows passive } \\
\text { cooling to occur in this } \\
\text { residence. }\end{array}$ & $\begin{array}{l}\text { The selection of stone } \\
\text { walls for walls walled } \\
\text { with wooden roof } \\
\text { structures without } \\
\text { ceilings creates the } \\
\text { comfort of a natural } \\
\text { space. }\end{array}$ & $\begin{array}{l}\text { The use of wood wall } \\
\text { material and woven } \\
\text { bamboo is additive to the } \\
\text { tropical climate, where the } \\
\text { shelter functions more as a } \\
\text { shade. So that natural } \\
\text { ventilation through } \\
\text { bamboo cushions can } \\
\text { realize the comfortable } \\
\text { conditions of the building. }\end{array}$ & $\begin{array}{l}\text { Design building } \\
\text { elements from the } \\
\text { residential layout and } \\
\text { building shape has } \\
\text { correlation to energy } \\
\text { conserving. }\end{array}$ \\
\hline $\begin{array}{l}\text { Design with Nature } \\
\text { Respect with site by } \\
\text { working with living } \\
\text { process. }\end{array}$ & $\begin{array}{l}\text { This can be seen in the } \\
\text { selection of local wood } \\
\text { board material with local } \\
\text { species that can be replanted }\end{array}$ & $\begin{array}{l}\text { This can be seen in the } \\
\text { selection of local } \\
\text { materials on the } \\
\text { foundation, walls and } \\
\text { main frame of the } \\
\text { house. Support the life } \\
\text { cycle of the Kotagede } \\
\text { environment. }\end{array}$ & $\begin{array}{l}\text { This can be seen in the } \\
\text { selection of bamboo } \\
\text { woven wall material with } \\
\text { local species that can be } \\
\text { replanted. }\end{array}$ & $\begin{array}{l}\text { This can be seen in the } \\
\text { design of building } \\
\text { elements and } \\
\text { architecture elements } \\
\text { that choose local } \\
\text { materials, taking into } \\
\text { account the local } \\
\text { natural life cycle. }\end{array}$ \\
\hline $\begin{array}{l}\text { Everyone is designer } \\
\text { Respect for user }\end{array}$ & $\begin{array}{l}\text { The majority of farmers are } \\
\text { inhabitants, where the need } \\
\text { to accumulate crops is } \\
\text { accommodated with the } \\
\text { public space in front. }\end{array}$ & $\begin{array}{l}\text { The location of the } \\
\text { house is adjusted to the } \\
\text { activities of the local } \\
\text { people with a specific } \\
\text { village name and a } \\
\text { different form of house. }\end{array}$ & $\begin{array}{l}\text { The majority of farmers } \\
\text { are inhabitants, where the } \\
\text { need to accumulate crops } \\
\text { is accommodated with the } \\
\text { public space in front. }\end{array}$ & $\begin{array}{l}\text { Determination of } \\
\text { residential layout and } \\
\text { spatial layout of the } \\
\text { house adjusted to the } \\
\text { needs of occupant } \\
\text { activities }\end{array}$ \\
\hline $\begin{array}{l}\text { Make Nature Visible } \\
\text { Effective design helps } \\
\text { inform us of our place } \\
\text { within nature. }\end{array}$ & $\begin{array}{l}\text { Flat geographical conditions } \\
\text { and more contoured to the } \\
\text { southeast adapted to the } \\
\text { Wonosoco hamlet } \\
\text { settlement patterns } \\
\text { generally spread, not } \\
\text { forming a mass group } \\
\text { This shows that the } \\
\text { residential design has } \\
\text { considered aspects of the } \\
\text { site. }\end{array}$ & $\begin{array}{l}\text { The residential design } \\
\text { follows the site } \\
\text { conditions, which are in } \\
\text { a solid environment. this } \\
\text { can be seen in the } \\
\text { spatial data layout and } \\
\text { orientation of the } \\
\text { Kotagede buildings }\end{array}$ & $\begin{array}{l}\text { The design of the dwelling } \\
\text { follows the site conditions, } \\
\text { this can be seen in the } \\
\text { spatial layout data of the } \\
\text { Selo house, where the } \\
\text { spread follows the } \\
\text { contours in Selo, Boyolali. }\end{array}$ & $\begin{array}{l}\text { Settlement patterns } \\
\text { adapt to local site } \\
\text { conditions, both } \\
\text { adjusting land contours } \\
\text { and environmental road } \\
\text { patterns help us realize } \\
\text { that we are in the } \\
\text { environment. }\end{array}$ \\
\hline
\end{tabular}

Source : Author Analysis, 2019

\section{Discussion}

After the data collection stage, data processing and data analysis are continued. The data processing and data analysis stage in this research study was carried out by comparing the design of the three case study buildings as samples of the coastal, lowland, and mountainous areas. Each building data is grouped according to Ecological Architecture parameters consisting of: Solution grows from a place, Ecological Accounting informs design, Design with Nature, everyone is my designer Make Nature Visible. 
From the discussion, it can be seen that for the three sample building studies, the selected cases show that related to the solution grow from place parameters. It can be seen that the choice of building materials, for instance, building frames, walls, and other architectural elements choose local materials. Data on Ecological accounting informs design parameters show that Design building elements from the residential layout and building shape correlate with energy conserving.

The design of building elements and architectural elements that choose local materials, taking into account the local natural life cycle, and this shows that three buildings implement the parameters Design with Nature. Moreover, regarding the parameters of building user involvement in the design, it appears that the determination of residential layout and spatial layout of the house are adjusted to the needs of occupant activities. This design is an application from the parameter everyone is a designer.

Besides that, all of the building has settlement patterns which adapted to local contour conditions, both adjusting land contours and environmental road patterns which help us realize that we are in the environment.

\section{CONCLUSIONS AND RECOMMENDATION}

Summary from the discussion above about Application of Ecological Architecture Concept on Javanese Traditional House in Central Java are :

1. The choice of building materials, both foundation, building frames, walls, and other architectural elements, choose local materials.

2. Design building elements from the residential layout and building shape to energy conserving.

3. The design of building elements and architectural elements that choose local materials, taking into account the local natural life cycle.

4. Determination of residential layout and spatial layout of the house adjusted to the needs of occupant activities.

5. Settlement patterns adapt to local site conditions, both adjusting land contours and environmental road patterns help us realize that we are in the environment.

From this study, it can be concluded that traditional houses apply the concept of ecological architecture in several aspects. This is influenced by site conditions, location, and climate conditions. This concept has been in the design of homes which was located on the coast, mountains, and lowlands, judging from the five parameters of the Ecological Design theory used.

From the results of this study about how traditional Javanese architecture applies the concept of ecological architecture in its design, this can also be applied by architects and planners designing a building and a built environment today. So it is hoped that harmony between the built environment and the natural environment and can achieve sustainability in architecture.

\section{REFERENCES}

[1] UN-Habitat, Sustainable Building Practices for Low Cost Housing: Implications for Climate Change Mitigation and Adaptation in Developing Countries (coping Paper), Nairobi: United Nations Human Settlements Programme (UN-Habitat), 2011. available http://www.unhabitat.org/downloads/docs/10785_1_59434 0.pdf, diakses 8 Oktober 2019.

[2] A. Hoballah, A., Sustainable Building: Driver to Transformative Change, SBCI (Symposium Philadelphia, October 11) p.6, 2011. UNEP,http:///www.unep.org/sbci/pdfs/Oct_Symposium/, diakses 8 Oktober 2019.

[3] S.V. Ryn and S. Cowel, Ecological Design, Tenth Anniversary Edition, Washington DC: Island Press, 2007.

[4] D.L. Bahry, Croosing Border: The Practice of Comparative Research, in Jarol B. Manheim and Richard C. Rich, Empirical Political Analysis: Research Methods in political Science, London: Longman Publisher, 1995.

[5] A. Lipjhart, The Comparable - Cases Strategy in Comparative Political Studies, Sage Publications Inc, Vol.8:No.2, 1975.

[6] Direktorat Jenderal Cipta Karya, Inventarisasi Arsitektur dan Permukiman Tradisional Wilayah Jawa, Direktorat Penataan Bangunan dan Lingkungan, Direktorat Jenderal Cipta Karya, Kementerian Pekerjaan Umum RI, 2018. 